\title{
Use of starch manufacturer residue in the production of inoculating biofertilizer
}

\author{
Utilização de resíduo de fecularia na produção de biofertilizante \\ inoculante
}

\author{
Paulo Agenor Alves Buenol \\ Edgar Lopes Balestri" \\ Rafael de Almeida Vidal Feres Rosiello"II \\ Cristian Coelho Silvalv \\ Bruna Lopes Gualdi ${ }^{\mathrm{V}}$ \\ Vitória Maria Almeida Teodoro de Oliveira ${ }^{\mathrm{VI}}$ \\ Júlio Barreto CristófolivII \\ Elizabete Satsuki Sekine VIII \\ Raquel de Oliveira Bueno ${ }^{\mathrm{IX}}$
}

\begin{abstract}
In the industrialization of cassava, effluents are generated capable of causing great impacts to the environment. One of these residues is called manipueira and its generation occurs by pressing the grated cassava mass. An alternative to the use of this industrial residue is its use as a culture medium in the multiplication of microorganisms useful in agriculture in the form of biological inoculants. The objective of this work was to evaluate the effectiveness of different concentrations of manipueira used as substrate in the development of the bacterium Bacillus subtilis and the fungus Trichoderma spp as biological control agents and plant growth promoters, aiming at the low cost of the agricultural protection process. The tests were carried out by means of a triple plating technique in culture medium

\footnotetext{
'Doutor, Departamento de Biodiversidade e Conservação da Natureza (DABIC), Universidade Tecnológica Federal do Paraná, Campo Mourão, PR, Brasil. pauloaabueno@gmail.com

"Mestrando, Programa de Pós Graduação em Engenharia de Edificações e Saneamento, Universidade Estadual de Londrina, Londrina, PR, Brasil. edgarlb@hotmail.com

I'I Graduado, Departamento de Biodiversidade e Conservação da Natureza (DABIC), Universidade Tecnológica Federal do Paraná, Campo Mourão, PR, Brasil. rosiellorafael@gmail.com

Iv Mestre, Departamento de Biodiversidade e Conservação da Natureza (DABIC), Universidade Tecnológica Federal do Paraná, Campo Mourão, PR, Brasil. cristian_coelho@yahoo.com.br

` Graduanda, Departamento de Biodiversidade e Conservação da Natureza (DABIC), Universidade Tecnológica Federal do Paraná, Campo Mourão, PR, Brasil. brulgualdi@gmail.com

VIGraduanda, Departamento de Química (DAQUI), Universidade Tecnológica Federal do Paraná, Campo Mourão, PR, Brasil. vihteodoroo@gmail.com

VII Mestre, Programa de Pós Graduação em Bioenergia, Universidade Estadual de Maringá, Maringá, PR, Brasil. juliocristofoli@hotmail.com

VIII Doutora, Departamento de Biodiversidade e Conservação da Natureza (DABIC), Universidade Tecnológica Federal do Paraná, Campo Mourão, PR, Brasil. essekine@gmail.com

\x Doutora, Departamento de Biodiversidade e Conservação da Natureza (DABIC), Universidade Tecnológica Federal do Paraná, Campo Mourão, PR, Brasil. quelloliveira@gmail.com
} 
containing manipueira, molasses and distilled water in different concentrations for both biological agents. The efficiency of the method, substract and organisms was measured through the calculation of colony forming units (CFU). The maximum production of CFU of the fungus Trichoderma spp was $1.2 \times 109$ CFU.mL -1 in a concentration of $175 \mathrm{~mL} . \mathrm{L}-1$ of manipueira, while for the bacterium Bacillus subtilis, the maximum production reached $6.49 \times 1011$ CFU .mL -1 in culture with concentration of $125 \mathrm{~mL}-1$ of the residue. Compared to commercial inoculants with concentration around $1 \times 108 \mathrm{CFU}$, the tested cultures were compatible with this value and still managed to overcome it, confirming its efficiency. Therefore, this is an excellent possibility to direct the use of environmental liabilities and to encourage the use of the biofertilizer by farmers who can produce it in their properties in an alternative way and with a low cost of production in relation to the commercial value.

Keywords: Biorreactor; Environmental liability; Applied Biotechnology; Sustainable agriculture; cassava wastewater

\section{Resumo}

$\mathrm{Na}$ industrialização da mandioca são gerados efluentes capazes de causar grandes impactos ao meio ambiente. Um desses resíduos é denominado manipueira e a sua geração se dá através da prensagem da massa de mandioca ralada. Uma alternativa de utilização desse resíduo industrial é seu aproveitamento como meio de cultura na multiplicação de micro-organismos úteis na agricultura na forma de inoculantes biológicos. O objetivo deste trabalho foi avaliar a efetividade de diferentes concentrações de manipueira utilizadas como substrato no desenvolvimento da bactéria Bacillus subtilis e do fungo Trichoderma spp como agentes de controle biológico e promotores de crescimento de plantas, visando ao baixo custo do processo de proteção agrícola. Os testes foram realizados por meio de uma técnica de triplo chapeamento em meio de cultura contendo manipueira, melaço e água destilada em diferentes concentrações para ambos os agentes biológicos. Madiu-se através do cálculo de unidades formadoras de colônia (CFU) a eficiência do método, meio de cultura e organismos. A produção máxima de CFU do fungo Trichoderma spp foi de 1,2×109 CFU.mL -1 em uma concentração de $175 \mathrm{~mL} . \mathrm{L}-1$ de manipueira, enquanto para a bactéria Bacillus subtilis, a produção máxima alcançou 6,49x1011 CFU .mL -1 em cultura com concentração de 125mL -1 do resíduo. Comparados aos inoculantes comerciais com concentração em torno de $1 \times 108 \mathrm{CFU}$, as culturas testadas foram compatíveis com esse valor e ainda conseguiram superá-lo, confirmando sua eficiência. Portanto, esta é uma excelente possibilidade de direcionar o uso de passivos ambientais e incentivar o uso do biofertilizante por agricultores que possam produzi-lo em suas propriedades de forma alternativa e com baixo custo de produção em relação ao valor comercial.

Palavras-chave: Biorreator; Passivo Ambiental; Biotecnologia Aplicada; Agricultura Sustentável; Manipuira 


\section{Introduction}

With the large population growth, the food industry needs to increase its production and in doing so can generate environmental problems, making the urban environment increasingly degraded. As a result, the impacts air, soil and water contamination have great significance in the physical, biotic and socioeconomic environments.

One of these major industries is the cassava flour producers (Manihot esculenta Crantz) belonging to the family Euphorbiaceae and native to tropical America. The main countries that grow it are located in Africa, Asia, Oceania and Latin America. It is a source of food rich in calories and carbohydrates (SOUZA et al., 2010).

In the cassava industrialization, the impacts are generated from the input of the raw material, with the washing of the roots which generates effluent and thus discharges into the water body with or without treatment. Another generated effluent is the one that results from the pressing of the mass of grated cassava, denominated manipueira. This by-product contains in its composition a percentage of the diferente constituents of the roots, such as starch, minerals, proteins and cyanogenic glycosides (ERNANDES; DELBIANCHI; MORAES, 2014).

The environmental problems caused by the inadequate disposal of this residue are due to its high concentration of biochemical oxygen demand (BOD). The BOD values of the manipueira range from $14,000 \mathrm{mg} \cdot \mathrm{L}-1$ to $34,000 \mathrm{mg} \cdot \mathrm{L}-1$. This data of BOD quantity provided by the industries is contrasting due to the different dilutions to which it is submitted during the procedure of root processing (DANTAS et al., 2017).

Because of this, there is the need to use manipueira, since it is an environmental liability, in other alternative sources. There is a special meaning when taking into account the economic viability of this substance, as it is an industrial waste and has high added value. These facts suggest the potential of industrial application for growing microorganisms. In order to reduce production costs to make the product competitive on the market, the use of industrial waste as a culture medium is an acceptable alternative since the raw material representes one of the main costs in the 
process. Trichoderma spp. are mycorrhizal fungi which have the ability to associate with plant roots providing gains in survival and productivity. Another feature is its preventive use against other fungi, such as Fusarium, Botrytis, Monilinia, Verticillium, Pythium, among others.

This genus of fungi has reproductive capacity, rapid growth, ability to survive under unfavorable conditions, efficient use of nutrients, high aggressiveness against phytopathogenic fungi, ability to promote plant growth and activate their defense mechanisms. Thus, they are successful as agents of biological control (RIBEIRO, 2009).

These fungi are of great economic importance for agriculture as they are capable of acting as disease control agents of various crop plants, also being growth promoters and inducers of plant resistance to diseases. Trichoderma can interact with the pathogen in a variety of ways, such as antibiosis, competition, parasitism, hypovirulence, predation or induction of host defense (MEDEIROS et al., 2017). The genera of plant-growth promoting rhizobacteria (PGPR) most studied as biological control agents are: Pseudomonas, Azospirillum, Rhizobium and Bacillus (ARAUJO, 2008). Bacillus spp. Are distinguished by high temperature tolerance, rapid growth in liquid cultures, ubiquity in soils, and it is considered a safe biocontrol agent to be applied (TANAKA et al., 2017). The mechanisms of control of the antagonist are diverse, standing out the process of antibiosis, competition, parasitism and predation. In addition, it also has the ability to induce host defense, looking promising for agriculture (REMUSKA e PRIA, 2007).

Bacillus subtilis promotes plant growth through its nitrogen fixation capacity, nutrient solubilization and phytormonium synthesis, besides the ability to promote soil improvement that ultimately influence plant germination and growth rate (RIBEIRO et al., 2011). Bacillus subtilis products have a good viability in the market due to the production of secondary metabolites that aid in the control of various agricultural pathogens, as well as to the production capacity of endospores resistant to high temperatures, which guarantees their permanence at the treatment site for a long period of time (VOSS, 2013). 
For the development of microorganisms, there are nutritional requirements so that nutrients are not lacking and to obtain a great growth. The composition of the culture medium should contain water, carbon, nitrogen, and some types of minerals for growth and sporulation. Furthermore, the parameters of $\mathrm{pH}$, dissolved oxygen and temperature must be controlled (CHAGAS et al., 2017). As a carbon source, it can be used cane and beet molasses, cereal starch, roots or tubers. As a source of nitrogen, the main substrate is soybean meal, water from the pressing of corn and hydrolyzed casein (CHAGAS et al., 2017).

Thus, the present work aims to evaluate the effectiveness of different concentrations of manipueira, an industrial byproduct of high potential polluter, used as substrate in the development of the bacterium Bacillus subtilis and the fungus Trichoderma spp as biological control agents and promoters of plant growth in order to promote low-cost agricultural protection, together with the benefit of providing an adequate destination for one of the major environmental liabilities of the flour and starch industries.

\section{Material e Methods}

The cassava residue known as manipueira used in this work was acquired in a flour industry of the Araruna City called Flour and Trade Industry Mandionorte Ltda. in Paraná State. A $2000 \mathrm{~mL}$ sample of this residue was sent to the environmental and agronomic analysis laboratory, Acqua Sollus, for the analysis of its chemical composition (Table 1 ) regarding the inert macronutrients in this residue.

Table 1 - Chemical composition of manipueira residue regarding macronutrients

\begin{tabular}{cccc}
\hline $\mathrm{pH}$ & $\begin{array}{c}\text { Nitrogen } \\
\left(\mathrm{g} \mathrm{kg}^{-1}\right)\end{array}$ & $\begin{array}{c}\text { Phosphorus } \\
\left(\mathrm{g} \mathrm{kg}^{-1}\right)\end{array}$ & $\begin{array}{c}\text { Potassium } \\
\left(\mathrm{g} \mathrm{kg}^{-1}\right)\end{array}$ \\
\hline 4,0 & 53,20 & 94,00 & 64,00 \\
\hline
\end{tabular}

Three cultures were prepared containing manipueira with $\mathrm{pH}$ corrected to 7.0, molasses and distilled water in different concentrations, both for the evaluation of 
the concentration of the biological agent Bacillus subtilis and for Trichoderma spp, all provided by companies that produce it for commercial purposes, having previously reported concentrations of $3 \times 10^{9} \mathrm{CFU} / \mathrm{mL}$ and $1.1 \times 10^{11} \mathrm{CFU} / \mathrm{mL}$, respectively.

After the serial dilution technique which required the addition of $10 \mathrm{ml}$ of the product to be tested in $90 \mathrm{ml}$ of diluent (corresponds to dilution $10^{-1}$ ), the tube was placed on the tube shaker in order to homogenize the solution. Subsequently, it was transferred $1 \mathrm{ml}$ of suspension to the second tube (corresponding to dilution $10^{-2}$ ) with a micropipette and sterilized tips, discarding the tip afterwards, and so on, counting the colonies in the plates, being plated in Petri dishes in triplicate (Figure 1).

Figure 1- Serial dilution followed by plating

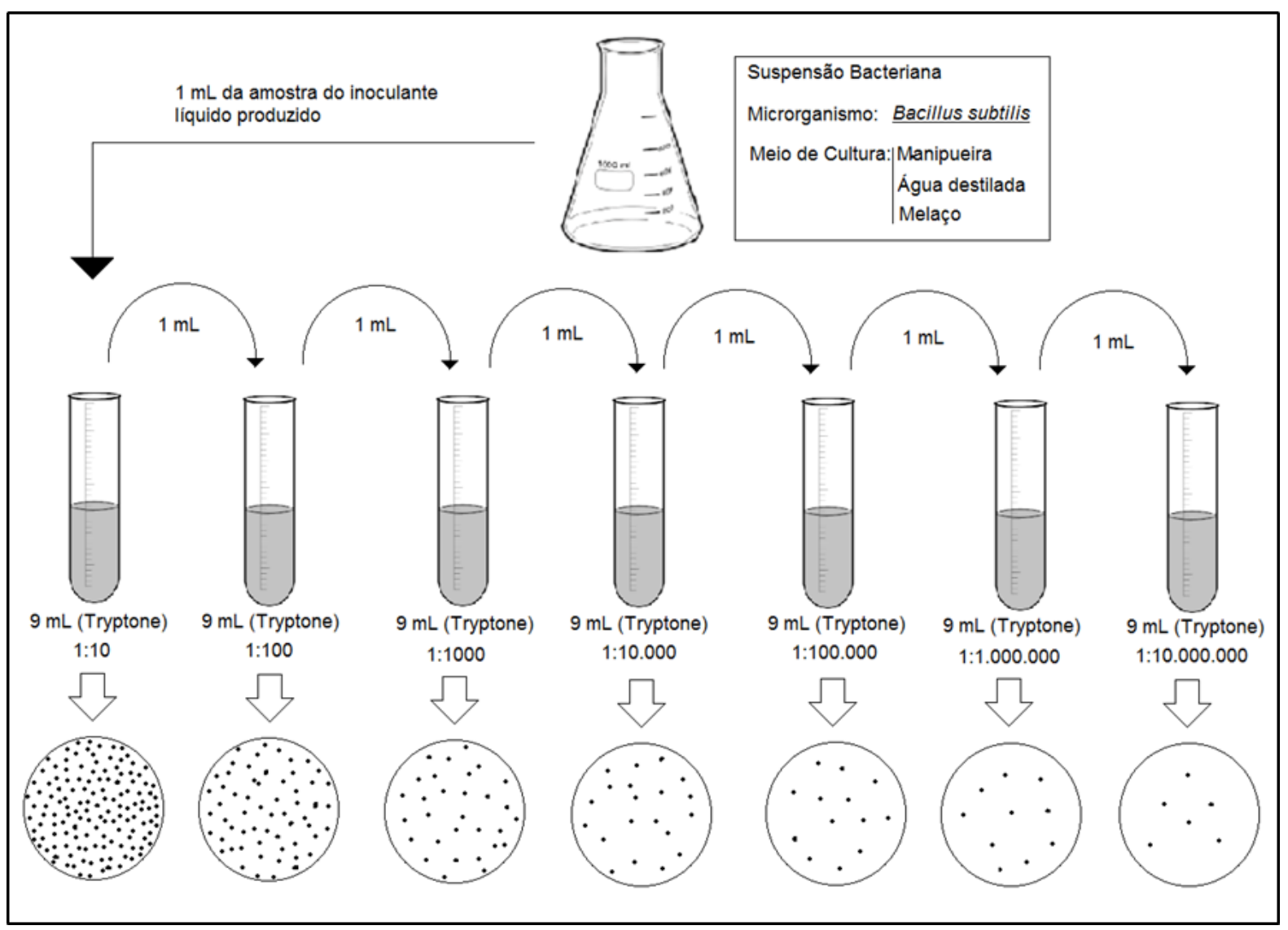

For both counts of colony forming units in one milliliter of inoculum, it was based on the methodology for quality control of biological products of the Brazilian Agricultural Research Agency (2012). (CFU / mL) = mean colony number on plaque $X$ 
sample dilution $X 10$. The ideal plaques for counting colonies are represented by the range of 30 to 300 CFU per plate. For each biological agent different methods are made with different concentrations.

\subsection{Trichoderma spp}

The microorganisms of the genus Trichoderma were granted by a company that produces it for commercial purposes, packaged in plastic packaging. According to the company responsible, it was possible to verify the presence of $1.1 \times 10^{11}$ CFU.mL $\mathrm{mL}^{-1}$ of the product sample. The tests were carried out at the Ecology Laboratory of the Department of Biodiversity and Nature Conservation (DABIC) at the Federal Technological University of Paraná, Campo Mourão Campus.

The culture medium was composed of manipueira in different concentrations and molasses with fixed concentration. Three batches were performed, with the following concentrations of manipueira: $50 \mathrm{~mL} \cdot \mathrm{L}^{-1} ; 125 \mathrm{~mL} \cdot \mathrm{L}^{-1}$ and $175 \mathrm{~mL} \cdot \mathrm{L}^{-1}$. The definite concentration of molasses was $15 \mathrm{~g} \cdot \mathrm{L}^{-1}$ in all batches and triplicates were performed for each concentration.

To prepare the pre inoculum, $10 \mathrm{~mL}$ of the fungi were inoculated into $400 \mathrm{~mL}$ of each culture medium and autoclaved at $121^{\circ} \mathrm{C}$ for 20 minutes. Then, these cultures were put on a shaker table for 72 hours at $150 \mathrm{rpm}$. This pre inoculum was prepared to be used in fungal culture within the airlift bioreactor.

The airlift bioreactor (Figure 2) with internal circulation has the following configuration: internal PVC tube with diameter of $50 \mathrm{~mm} \times 54 \mathrm{~cm}$ in height; external PVC tube with diameter of $100 \mathrm{~mm} \times 70 \mathrm{~cm}$ in height, stainless steel tripod with $4 \mathrm{~cm}$ high and 2 caps of $100 \mathrm{~mm}$. Power, pH control, air intake and exhaust were drilled in the top cover and a $4 \mathrm{~mm}$ silicone hose used outside (traduzi conforme está escrito no artigo mas não faz sentido em português, favor rever). The bioreactor has a useful volume of 5 liters. In order to disperse the air inside the bioreactor, it was used a diffuser stone and an Atman compressor model A230. Exhaust gases were treated by an airlock containing $70^{\circ}$ alcohol. Elastic o-rings were used to fully seal the upper and lower covers. 
Regarding the temperature, it was under the effect of a thermostat coupled to a resistance of cartridge of 100 watts with the purpose of heating the culture when necessary in a temperature between $28 \pm 1^{\circ} \mathrm{C}$.

Figure 2 - Alternative airlift bioreactor made of PVC material

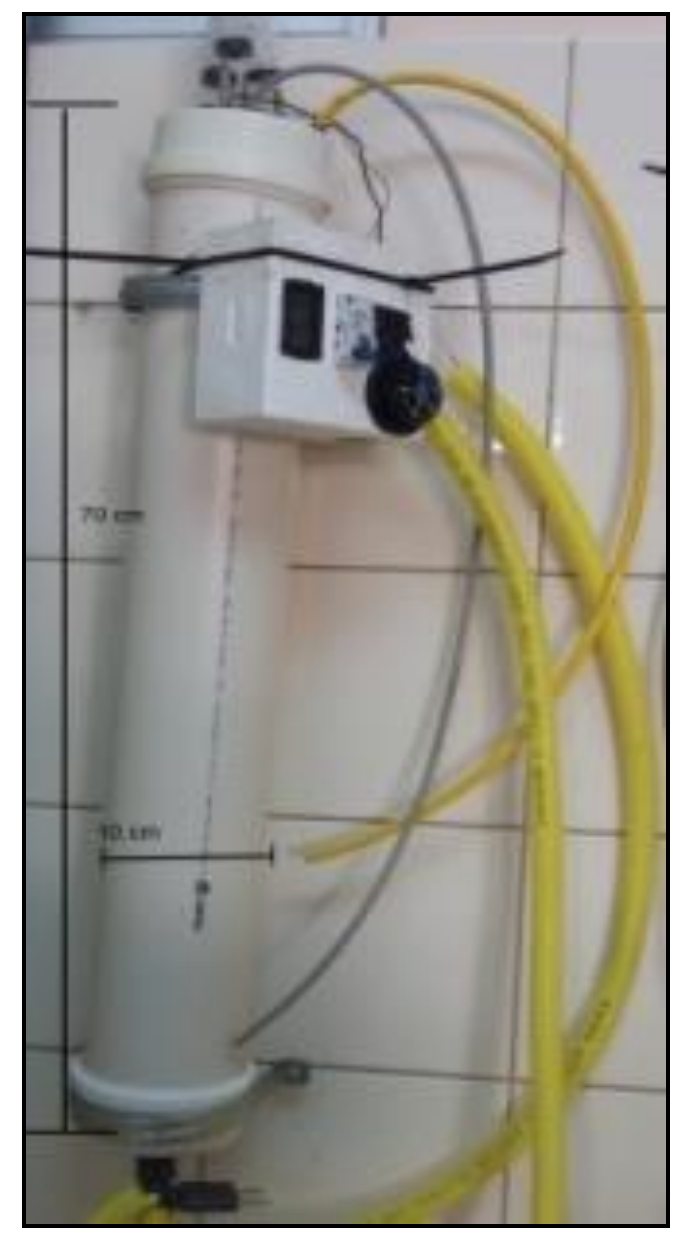

The parameters, temperature, dissolved oxygen and $\mathrm{pH}$ were monitored using the YSI model 6920 V2 multi-parameter probe at 12-hour intervals, totaling 7 periods for each culture (pre and inoculum).

\subsection{Bacillus subtilis}

The tests of production of the liquid inoculant were carried out at the CELF company - Renewable Energies and Bioenergy of Campo Mourão, Paraná. Tests were done weekly for three months using the microorganism Bacillus subtilis as the biological component of the final inoculant and the industrial residue of cassava 
flour and starch manufacturers, manipueira, as a culture medium for these organisms. The bacterial strain used in the tests belongs to the isolate of Bacillus subtilis denominated UFPEDA - 764, in a concentration previously reported on a label of $3 \times 10^{9} \mathrm{CFU} / \mathrm{mL}$ of a commercial liquid inoculant.

The methodology of evaluation of the concentration of the biological agent Bacillus subtilis in manipueira was adapted from Cardoso (2009) in which three cultures of different manipueira / molasses ratio were formulated (Table 2)

Table 2 - Composition of culture media formulated for growth promotion test

\begin{tabular}{|c|c|c|c|c|c|c|}
\hline & \multicolumn{2}{|c|}{ Culture $1\left(\mathrm{M}_{1}\right)$} & \multicolumn{2}{|c|}{ Culture $2\left(\mathrm{M}_{2}\right)$} & \multicolumn{2}{|c|}{ Culture $3\left(\mathrm{M}_{3}\right)$} \\
\hline & $\begin{array}{l}\text { Volume } \\
(\mathrm{mL})\end{array}$ & $\begin{array}{l}\text { Manipueira / } \\
\text { molasses ratio }\end{array}$ & $\begin{array}{l}\text { Volume } \\
(\mathrm{mL})\end{array}$ & $\begin{array}{l}\text { Manipueira / } \\
\text { molasses ratio }\end{array}$ & $\begin{array}{l}\text { Volume } \\
(\mathrm{mL})\end{array}$ & $\begin{array}{l}\text { Manipueira / } \\
\text { molasses } \\
\text { ratio }\end{array}$ \\
\hline Manipueira & 62,5 & \multirow{3}{*}{$15: 1$} & 125 & \multirow{3}{*}{$5: 1$} & 250 & \multirow{3}{*}{$8: 1$} \\
\hline Molasses & 4 & & 25 & & 30 & \\
\hline $\begin{array}{l}\text { Distilled } \\
\text { water }\end{array}$ & 187,5 & & 125 & & 55 & \\
\hline
\end{tabular}

For each culture, a minimum of $250 \mathrm{ml}$ was formulated being separated into 5 Erlenmeyer flasks with $50 \mathrm{~mL}$ containing one gram of the commercial liquid inoculant added in each of the culture in order to perform tests in triplicate for growth on Petri dishes with agar nutrient.

Each day, for each of the 5 Erlenmeyer containing $50 \mathrm{~mL}$ of the inoculant, a serial dilution was made in search of the appropriate or ideal dilution to count the colony forming units. The plating of the respective dilutions were done in triplicate for the calculation of the quantitative average of the colony forming units. An example of an ideal plaque is the one that can be observed in the dilution $10^{-8}$ of (Figure 3), counting $52 \mathrm{CFU}$ on the agar plate, resulting in the approximate concentration of $5 \times 10^{10} \mathrm{CFU} / \mathrm{g}$ in the final inoculum produced. 
Figure 3 - Sequence of Bacillus subtilis plaques in nutrient agar culture

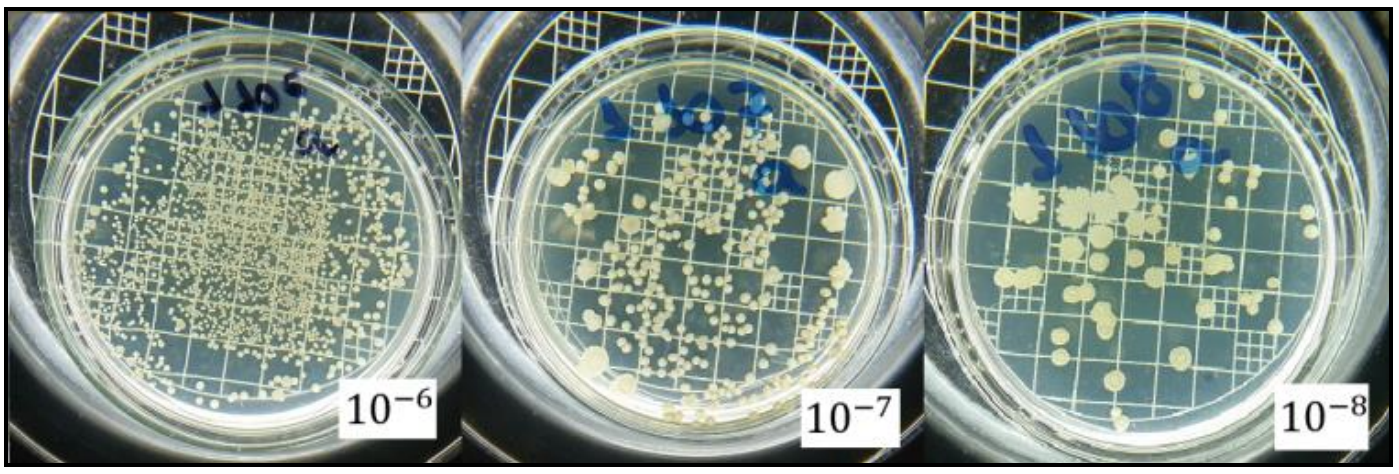

At the end of each counting day, all plates were examined quickly to ascertain the uniformity of the morphology of the organisms in them, looking for plates free of contaminants. However, when some plaques showed different morphologies of the colonies, the Gram staining was made to differentiate them into Gram positive and negative as well as to confirm the presence of Bacillus subtilis according to their purple coloration, being a bacterium representative of the Gram positive group, as well for its rod format (Figure 4).

Figure 4 - Microscope view of Bacillus subtilis after Gram staining

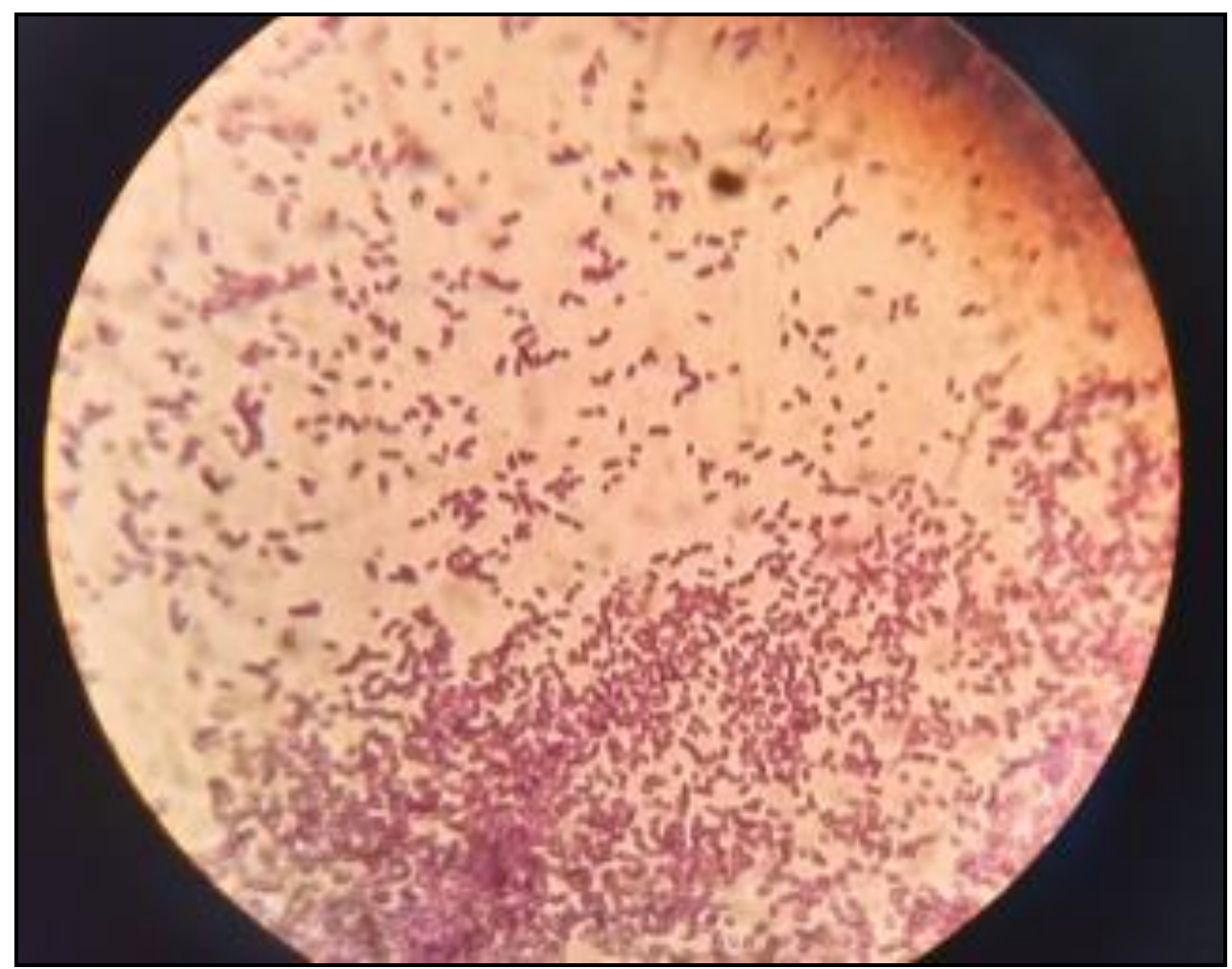




\section{Results and Discussion}

\subsection{Trichoderma spp}

A suitable culture medium is of extreme importance for the vegetative production of fungi in liquid media, and its composition must always have nitrogen, carbon and mineral sources (FONSECA NETO et al., 2016). In the alternative culture medium studied, different concentrations of manipueira were tested in order to evaluate its effectiveness and to meet the needs of the microorganisms.

From the test of Colony Forming Units, it was possible to analyze the vegetative growth of the pre inoculum (Table 3), being this growth fundamental for the process of cultivation in the bioreactor. The concentration of the fungi was divided into each substrate concentration.

Table 3 - Vegetative growth (CFU. $\mathrm{mL}^{-1}$ ) of Trichoderma spp. present in the pre inoculum produced by the different concentrations of manipueira

\begin{tabular}{lccc}
\hline \multicolumn{1}{c}{ Concentration } & Solution 1 & Solution 2 & Solution 3 \\
\hline $50 \mathrm{~mL} \cdot \mathrm{L}^{-1}$ & $4,6 \times 10^{8}$ & $7,8 \times 10^{7}$ & $3,6 \times 10^{8}$ \\
$125 \mathrm{~mL} \cdot \mathrm{L}^{-1}$ & $5,6 \times 10^{8}$ & $5,2 \times 10^{8}$ & $5,4 \times 10^{8}$ \\
$175 \mathrm{~mL} \cdot \mathrm{L}^{-1}$ & $1,2 \times 10^{9}$ & $4,5 \times 10^{8}$ & $6,2 \times 10^{8}$ \\
\hline
\end{tabular}

With these results, it was possible to prove the effectiveness of the manipueira as a culture medium, since the highest growth was $1.2 \times 10^{9} \mathrm{CFU} . \mathrm{mL}^{-1}$, surpassing semisolid culture medium substrates with $15 \mathrm{gL}^{-1}$ glucose of corn and $5 \mathrm{gL}^{-1}$ of soybean meal for the production of Bacillus thuringiensis tolworthi, in which the culture medium was boiled and stirred constantly, reaching a maximum growth of $3.8 \times 10^{8}$ CFU.mL ${ }^{-1}$ (VALICENTE e ZANASI, 2005).

For the production of Trichoderma spp. in submerged media, the culture medium that provided the highest conidia production in isolates was the inactivated 
yeast medium, which is obtained from the fermentation of sugarcane. It showed a maximum yield of conidia $\mathrm{mL}^{-1}$ of $1.2 \times 108$ (HADDAD, 2014).

After the inoculation in the bioreactor, the aeration was suspended from the low dissolved oxygen concentration, in a range of $1 \mathrm{mg} \cdot \mathrm{L}^{-1}$, and then it was reperformed the Colony Forming Units test to analyze fungal growth in the bioreactor (Table 4) and to check if the product was in an ideal concentration for application.

Table 4 - Vegetative growth (CFU.mL-1) of Trichoderma spp. present in the inoculum produced in alternative airlift bioreactor by the different concentrations of manipueira.

\begin{tabular}{lccc}
\hline Concentration & Solution 1 & Solution 2 & Solution 3 \\
\hline $50 \mathrm{~mL} . \mathrm{L}^{-1}$ & $3,7 \times 10^{8}$ & $1,1 \times 10^{9}$ & $1,5 \times 10^{7}$ \\
$125 \mathrm{~mL} \cdot \mathrm{L}^{-1}$ & $1 \times 10^{9}$ & $1 \times 10^{6}$ & $1,2 \times 10^{8}$ \\
$175 \mathrm{~mL} \cdot \mathrm{L}^{-1}$ & $3,9 \times 10^{8}$ & $5,3 \times 10^{7}$ & $1,2 \times 10^{9}$ \\
\hline
\end{tabular}

The productivity of the bioreactor is evidenced, since in this equipment it was obtained a maximum growth of $1.2 \times 10^{9} \mathrm{CFU} \cdot \mathrm{mL}^{-1}$, when compared to related literature. For the production of biosurfactant by Bacillus subtilis in manipueira using a Pilot fermenter with a 40 liter volume, it was found the maximum presence of $2.3 \times 10^{9} \mathrm{CFU} \cdot \mathrm{mL}^{-1}$ in 24 hours of observation (BARROS, 2007).

As a result, it was possible to confirm the effectiveness of the equipment and the concentrations of manipueira used, since it was possible the growth of the fungi post inoculation with yield in the different concentrations of the alternative medium.

The production of Colony Forming Units in the alternative airlift bioreactor ranged from $1 \times 10^{6}$ to $1.2 \times 10^{9} \mathrm{CFU} \cdot \mathrm{mL}^{-1}$ before the proposed tests. However, there was the growth of another colony morphologically different from the genus Trichoderma (Figure 5), because these have characteristics of rapid growth, filling the whole plate, after a few days of incubation and in addition, the colony becomes white with a cottony aspect, passing to light green and later to dark green with white 
borders (SANTIN, 2008). A colonization of these groups was performed to identify the correct colonies to perform the quantification (Figure 6).

Figure 5 - Plates with BDA + Triton X-100, there being two types of colonies morphologically different

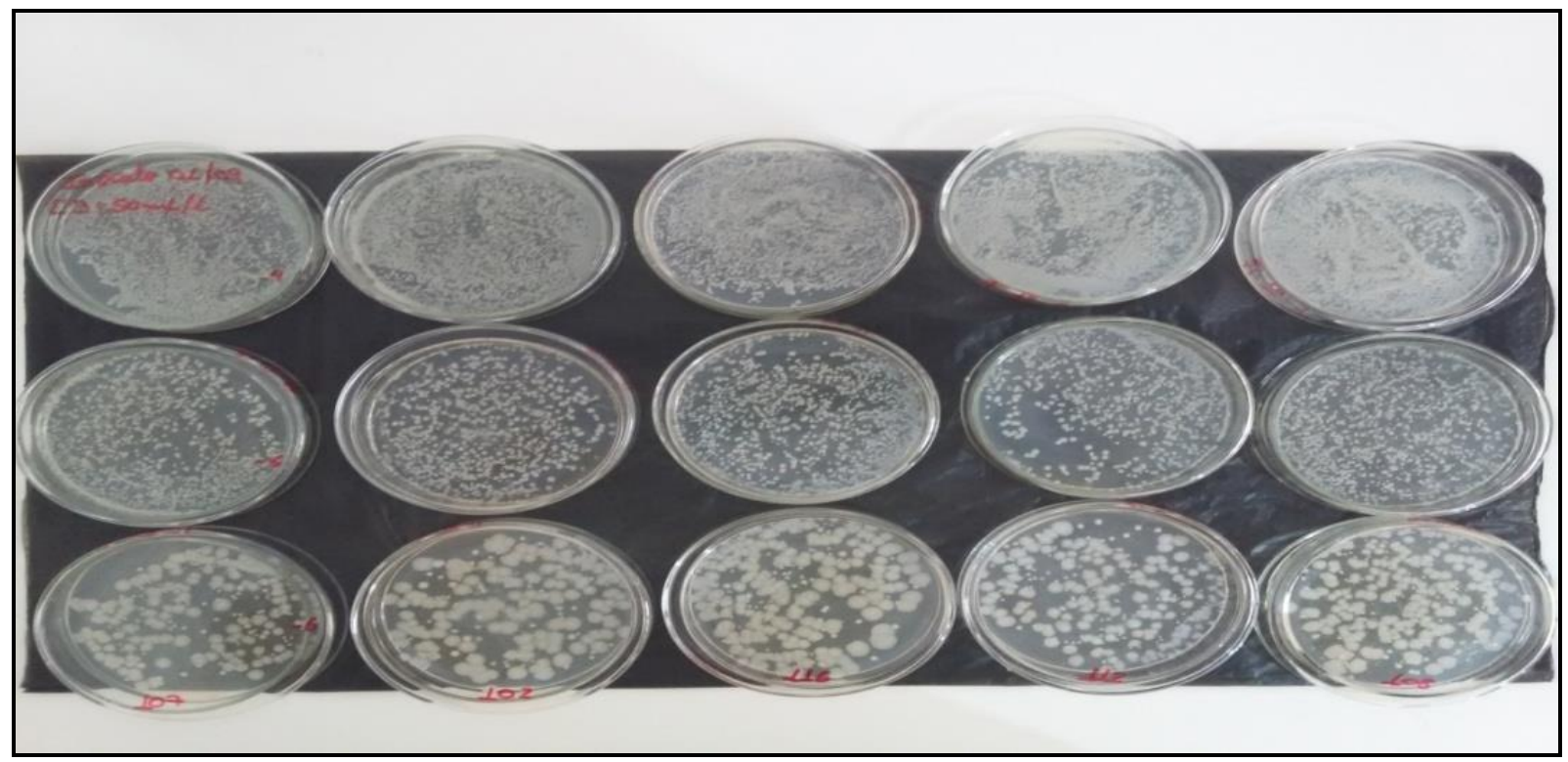

Source: Own Authorship

Figure 6 - Colonies of Trichoderma spp.

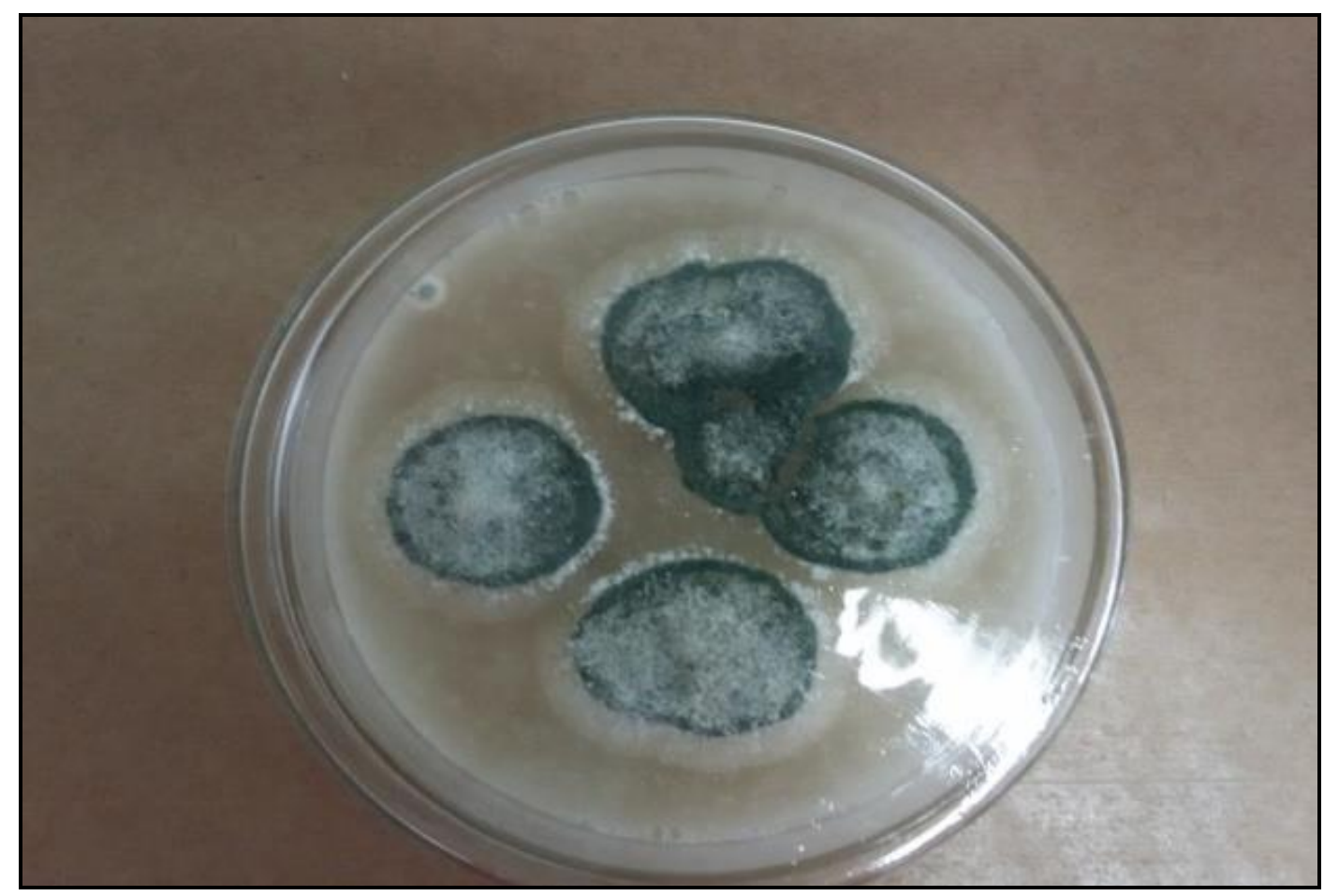

Source: Own Authorship 
The different concentrations of manipueira were tested for the growth of CFUs. It was verified that there is no difference in CFU growth in the different concentrations studied, since the Kruskal-Wallis test resulted in a value of $\mathrm{p}=0.6703 ; \mathrm{H}=0.8$ and degrees of freedom $=2$ (Figure 7). Thus, it is stated that the growths in the plating are equally efficient regardless of the substrate concentration being tested.

Figure 7 - Concentration of manipueira $\left(\mathrm{mL}^{-L^{-1}}\right)$ showing its growth of Trichoderma spp.

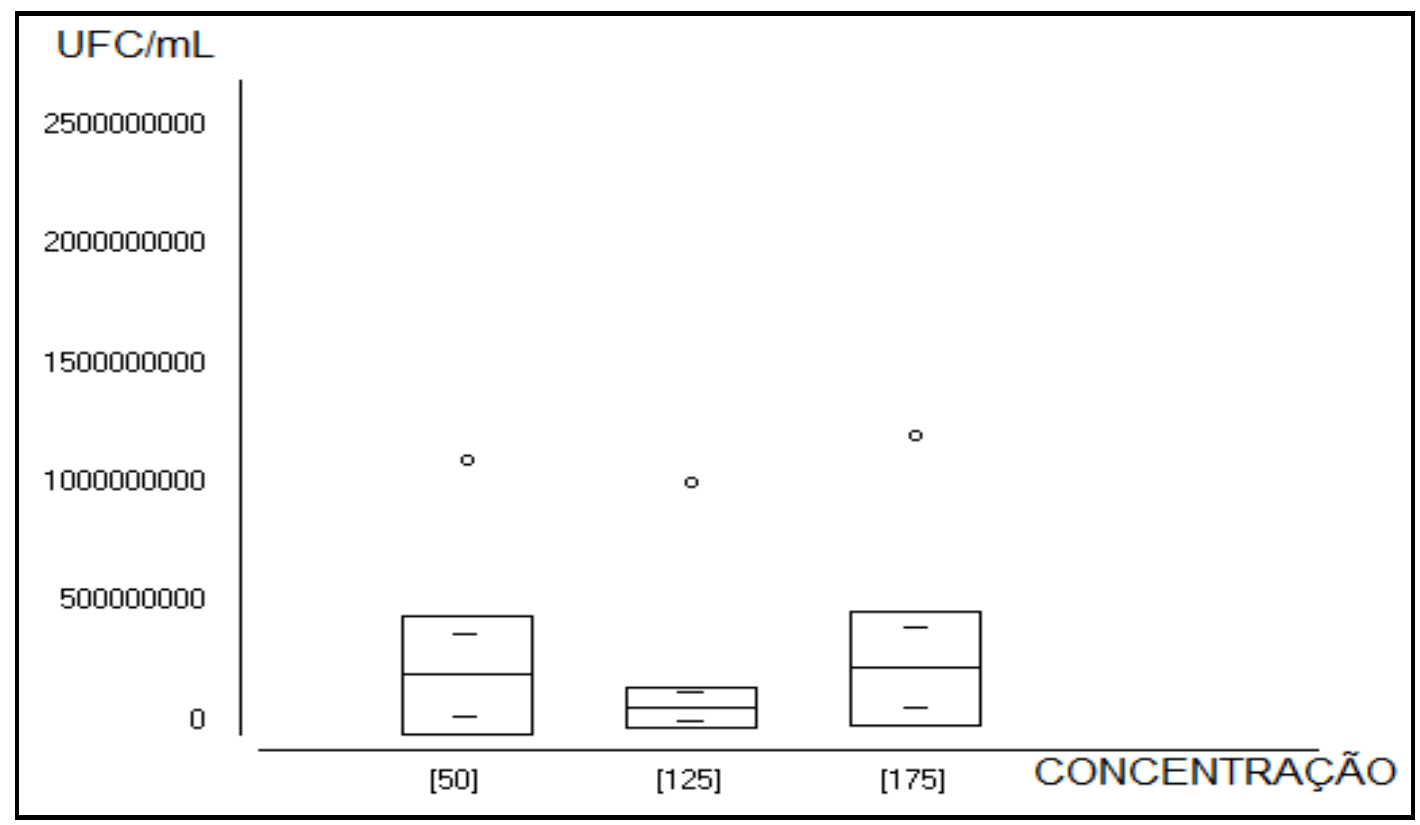

At the same time, it is proved by arithmetic means that the data are numerically different, but not statically, in which the arithmetic averages present close values (Table 5).

Table 5 - Values of the arithmetic means (CFU. $\mathrm{mL}^{-1}$ ) of each concentration studied

\begin{tabular}{lc}
\hline Concentration & Arithmetic mean \\
\hline $50 \mathrm{ml} . \mathrm{L}^{-1}$ & $4,9 \times 10^{8}$ \\
$125 \mathrm{ml} . \mathrm{L}^{-1}$ & $3,7 \times 10^{8}$ \\
$175 \mathrm{ml} . \mathrm{L}^{-1}$ & $5,4 \times 10^{8}$ \\
\hline
\end{tabular}


As the substrate concentrations were equally efficient, a t-test was performed to compare all the growths obtained with the ideal reference concentration for application of the product. The average for the t test was in accordance with Haddad's (2014) study, in which the genus Trichoderma was tested for control of Sclerotinia sclerotiorum (white mold) and also for the promotion of soybean growth. With the minimum concentration of $1 \times 10^{7}$ conidia $\mathrm{mL}^{-1}$, there was an efficiency of $94 \%$ inhibition of the germination of the pathogen. With the execution of the t-test for a sample, the mean of the population used (blue line) of $1 \times 10^{7}$ (Figure 8 ) and bilateral $p$ equal to 0.0229 were observed, indicating that the concentrations obtained by manipueira are higher than the minimum proposed by Haddad (2014) and thus feasible for application.

Figure 8 - Vegetative growth (CFU. $\mathrm{mL}^{-1}$ ) of all tests conducted in the airlift bioreactor

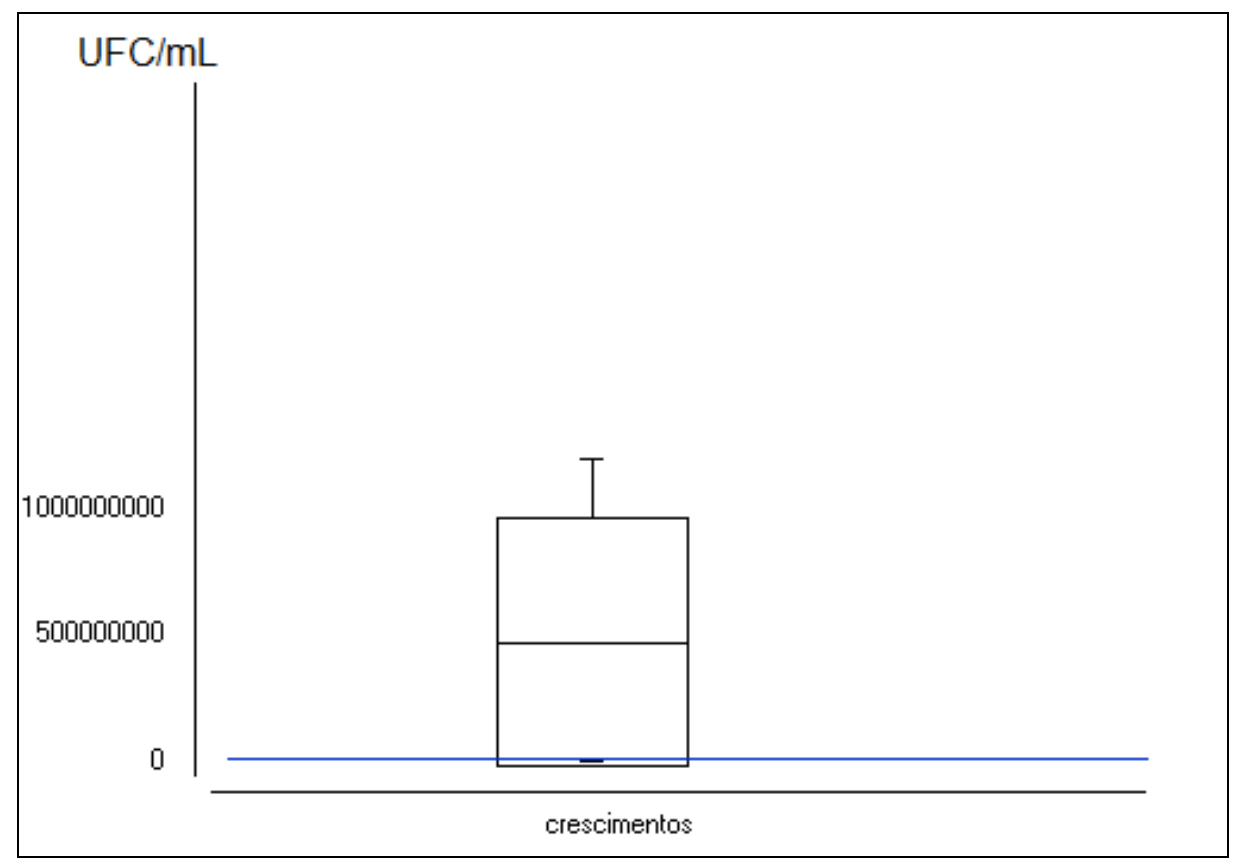

Considering that the concentration of $125 \mathrm{~mL}^{\mathrm{L}} \mathrm{L}^{-1}$ was the one with the lowest growth, it is recommended to use the highest concentration, $175 \mathrm{~mL} \cdot \mathrm{L}^{-1}$, so a characteristic can be given to this effluent since in this concentration a minimum fungal growth of $5.3 \times 10^{7} \mathrm{CFU} . \mathrm{mL}^{-1}$ was achieved, being ideal for the application of the product. 
According to Júnior et al., (2009), it was carried out tests with different isolates of the genus Trichoderma in common bean crop to combat Sclerotinia sclerotiorum, resulting in a good use of these fungi with concentration of $2 \times 10^{7}$ conidia. $\mathrm{mL}^{-1}$. They were applied during the pre-flowering of the 'Pérola' bean and during full flowering. As a result, it was achieved a percentage of parasitization of fungi Trichoderma spp. on white mold in the range of $93 \%$.

The interaction of the Brachiaria straw together with the application of Trichoderma harzianum in soybean crops achieved optimum efficiency. 0; 0.5; 1 and 1.5 L. ha ${ }^{-1}$ of the T. harzianum inoculum with concentration of $2 \times 10^{9} \mathrm{CFU} . \mathrm{mL}-1$ were applied in plots cultivated with and without Brachiaria. There was an increase in the number of $S$. sclerotiorum sclerotium parasitized by Trichoderma harzianum in the presence of straw, increasing soybean production due to the reduction of white mold incidence (GÖRGEN et al., 2009).

\subsection{Bacillus subtilis}

The data show that the formulation of culture 2 was more successful for the development of Bacillus subtilis, containing up to ten times more microorganisms compared to the others at the end of the process (Table 6).

Table 6 - Maximum concentration of Bacillus subtilis found in each culture

\begin{tabular}{lrrr}
\hline & Culture 1 $\left(\mathrm{M}_{1}\right)$ & Culture 2 $\left(\mathrm{M}_{2}\right)$ & Culture $3\left(\mathrm{M}_{3}\right)$ \\
\hline $\begin{array}{l}\text { Maximum } \\
\text { concentration of } \\
\text { microorganisms } \\
(\mathrm{CFU} / \mathrm{g})\end{array}$ & $2,91 \times 10^{10}$ & $6,49 \times 10^{11}$ & $5,36 \times 10^{10}$ \\
\hline
\end{tabular}

Source: Own Authorship

It was observed (Figure 9) that all cultures produced for testing had concentrations greater than $1 \times 10^{10} \mathrm{CFU} / \mathrm{g}$ on at least one of the five days after the start of the counting week, with emphasis on culture $2\left(M_{2}\right)$, formulated with $45 \%$ 
manipueira, 45\% distilled water and 10\% molasses which reached approximately $6 \times 10^{11} \mathrm{CFU} / \mathrm{g}$ on the fifth day of plating.

Culture 3 had the highest concentration of manipueira in the final inoculant and it reached its apex of microbial concentration on the third day in a shaker table, reaching approximately $5 \times 10^{10} \mathrm{CFU} / \mathrm{g}$ on the third day. However, such concentration decreased to $5 \times 10^{9} \mathrm{CFU} / \mathrm{g}$ on the fourth day and $6 \times 10^{8} \mathrm{CFU} / \mathrm{g}$ on the fifth day, differing from the other two cultures that continued their rise in concentration of microorganisms during the five days.

Figure 9 - Evaluation of the microbial concentration of Bacillus subtilis for five consecutive days for each culture.

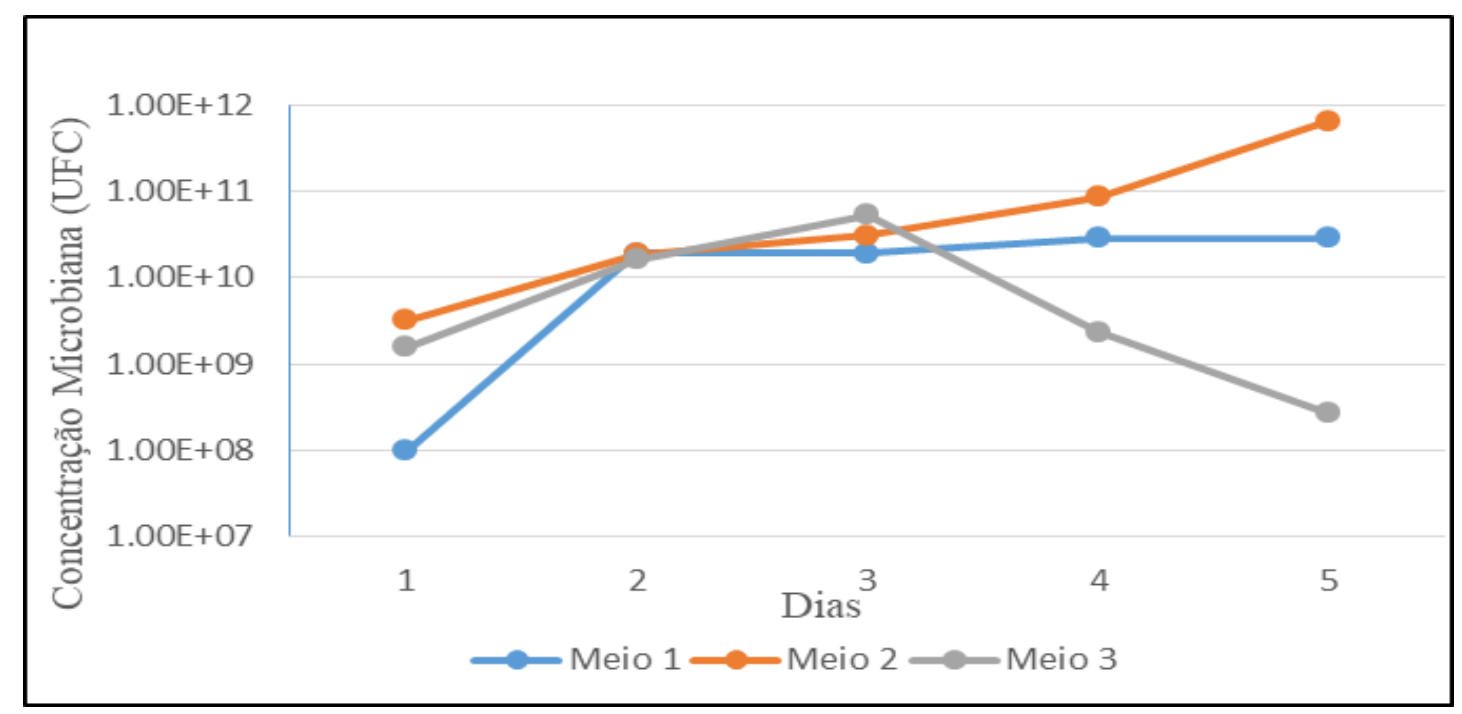

Source: Own Authorship

The possible differentials of the culture with better performance are probably related to its more balanced composition of nutrients, since it has a manipueira I molasses ratio of approximately 5: 1 . This relation with higher concentration of molasses and a manipueira intermediate could have been the optimum point of yield in the multiplication of the microorganisms.

Molasses is considered a good substrate for the cultivation of lactic acid bacteria because it is a substrate rich in fermentable sugars and minerals such as manganese, magnesium, phosphorus, potassium, zinc, sodium and calcium (VALICENTE et al., 
2018). This substrate complements the fulfillment of the nutritional needs of the microorganisms, besides being economically feasible due to the low value added to the product (VALICENTE et al., 2018).

Furthermore, in the experiments with manipueira for multiplication of Trichosporon sp., Efing and Wosiack (1998) obtained results similar to those found in this work in which the intermediate concentration medium conditions were more favorable for the development of the microorganism than the smaller ones and of greater concentration. The author explains that in higher concentrations, the oxygen level is lower due to the high organic matter content of the culture, reducing the rate of formation of new cells.

On the other hand, the culture with the lowest concentrations has oxygen more available, but the microorganisms rapidly deplete the available nutrients. Concluding, therefore, that the ideal concentrations for the development of microorganisms are those that reach the balance between available nutrients and oxygen dissolved in the medium. This may justify the higher concentration of microorganisms in the M2 formulation, providing the oxygen and nutrient load ideal for their development.

The use of manipueira as fertilizer is an interesting alternative for agricultural reuse, for the possibility of transforming a problematic residue into an organic input to grow species, for economy in composition and reduction of impacts (CARDOSO, 2009)

A new test of inoculum production with the same proportions of culture 2 was carried out, getting concentrations very close to those previously reached, in the range of $1 \times 10^{10}$ to $1 \times 10^{11} \mathrm{CFU}$ per gram of the final inoculant, reaffirming its efficiency and certifying that this is the most balanced formulation.

\section{Final Considerations}

Based on the experiment, it can be concluded that the residue manipueira can be used as culture medium for production in liquid medium of Trichoderma spp. in alternative airlift bioreactor. The presence of these microorganisms was verified in all 
the batchings and concentrations tested and only one of these would not be efficient for application.

According to the statistical test, it was possible to affirm that there is no difference of growth in the three concentrations used, so the concentration of $175 \mathrm{~mL} \cdot \mathrm{L}^{-1}$ can be used, since it is an agroindustrial residue having the ability to generate environmental impacts and it has low cost.

Manipueira has shown to be a good alternative as a culture medium for the development of Bacillus subtilis reaching concentrations of up to $6 \times 10^{11}$ CFU per gram of the biological inoculant when formulated with $10 \%$ molasses and corrected to $\mathrm{pH}$ 7, providing more viable cells per seed than that established by the Brazilian legislation. Therefore, it is effective for use as a biofertilizer.

Thus, for future use of the manipueira as a substrate for the production of microorganisms without autoclaving, there may be a greater saving in relation to the costs with preparation of the substrate and the application of the product in the field to prove the applicability of these microorganisms.

\section{References}

ARAUJO FF. Inoculação de sementes com Bacillus subtilis, formulado com farinha de ostra e desenvolvimento de milho, soja e algodão. Ciênc. agrotec. 2008; 32(2):456-462.

BARROS FFC. Estudo das variáveis de processo e ampliação de escala na produção de biossurfactante por Bacillus subtilis em manipueira. [thesis]. Campinas: Faculdade de Engenharia de Alimentos, Universidade Estadual de Campinas/UNICAMP; 2007. 117 p.

CARDOSO E. et al. Use of Manihot esculenta, crantz processing residue as biofertilizer in corn crops. Research Journal of Agronomy. 2009; 3: 1-8.

CHAGAS LFB, CHAGAS JÚNIOR AF, SOARES LP, FIDELIS RR. Trichoderma na promoção do crescimento vegetal. Revista de Agricultura Neotropical 2017, 4(3):97-102.

DANTAS MSM, ROLIM MM, BONFIM-SILVA EM,Franca e Silva EF, Silva GF. The use of 'manipueira' wastewater derived from cassava processing as organic fertilizer in sunflower cultivation. Austr Journ Crop Science 2017; 11(7):861-867. 
EFING LMAC, WOSIAK G. Estabelecimento de condições de cultivo de uma cepa de Trichosporon sp. Isolada de manipueira. B. CEPPA. 1998; 16:23-36.

Embrapa-Empresa Brasileira de Pesquisa Agropecuária. Metodologia para a viabilidade de conídios - unidade formadora de colônia. 2012. Embrapa Meio Ambiente. Jaguariúna, 2012.

ERNANDES S, DEL BIANCHI V, MORALES IO. Comparative Studies of Bacillus thuringiensis var. israelensis Metabolism in Different Concentrations of Cassava Flour Processing Waste Based Media. Adv Biosci Biotechnol. 2014; 5(12):978-983.

FONSECA NETO J, DANTAS MMA, SILVA FHA, CRUZ BLS, AMBRÓSIO MMQ, NASCIMENTO RSC. Efeito de adubo verde e Trichoderma harzianum na sobrevivência de Fusarium solani e no desenvolvimento do meloeiro. 2016; 10(1):44-49.

GÖRGEN CA, NETO ANS, CARNEIRO LC, RAGAGNIN V, JUNIOR ML. Controle do mofobranco com palhada e Trichoderma harzianum 1306 em soja. Pesq. agropec. bras. 2009; 44(12):1583-1590.

HADDAD PE. Avaliação de isolados de Trichoderma spp. para o controle de Sclerotinia sclerotiorum e Meloidogyne incognita em soja e produção em meios líquidos. [dissertation]. São Paulo: Instituto Biológico da Agência Paulista de Tecnologia dos Agronegócios; 2014. 102 p.

JÚNIOR ML, GERALDINE AM, CARVALHO DDC. Controle biológico de patógenos habitantes do solo com Trichoderma spp., na cultura do feijoeiro comum. Embrapa Arroz e feijão, Goias. Circular técnica 85.

MEDEIROS HA, ARAÚJO FILHO JV, FREITAS LG, CASTILLO P, RUBIO MB, HERMOSA R, MONTE E. Tomato progeny inherit resistance to the nematode Meloidogyne javanicalinked to plant growth induced by the biocontrol fungus Trichoderma atroviride. Sci. Rep. 2017; 40216(7): 1-13.

REMUSKA AC, PRIA MD. Efeito de Bacillus thuringiensis e Trichoderma sp. no crescimento de fungos fitopatogênicos. Publicatio UEPG: Ciências Exatas e da Terra, Ciências Agrárias e Engenharias. 2007; 3(13): 31-36.

RIBEIRO RD, SEI FB, LEITE MS. Bacillus subtilis. agente de controle biológico e promotor de crescimento em plantas. Jornal Dia de Campo [Internet]. $2011 \mathrm{Apr}$ 18 [cited 2018 mai 01]. Controle Biológico. Available from: http://www.diadecampo.com.br/zpublisher/materias/Materia.asp?id=24104\&se cao=Agrotemas 
RIBEIRO TS. O fungo Trichoderma spp. no controle de fitopatógenos: dificuldades e perspectivas. [monograph]. Porto Alegre: - Faculdade de Agronomia, Universidade Federal do Rio Grande do Sul/UFRGS; 2009.

SANTIN RCM. Potencial do Uso dos Fungos Trichoderma spp. e Paecilomyces lilacinus no Biocontrole de Meloidogyne incognita em Phaseolus vulgaris [thesis]. Porto Alegre: Faculdade de Agronomia, Universidade Federal do Rio Grande do Sul/UFRGS; 2008. 91 p.

SOUZA MJL, et al. Características agronômicas da mandioca relacionadas à interação entre irrigação, épocas de colheita e cloreto de mepiquat. Acta Scientiarum Agronomy. 2010; 32: 45-53.

TANAKA K, FUKUDA M, AMAKI Y, SAKAGUSHI T, INAI K, ISHIHARA A, NAKAJIMA H. Importance of prumycin produced by Bacillus amyloliquefaciens SD-32 in biocontrol against cucumber powdery mildew disease. 2017; 77,(12): 2419-2428.

VALICENTE FH, LANA UGP, PEREIRA ACP, MARTINS JLA, TAVARES ANG. Riscos à Produção de Biopesticida à Base de Bacillus thuringiensis. Circ Técnica EMBRAPA Milho e Sorgo. Sete Lagoas,2018.

VALICENTE FH, ZANASI RF. (2005). Uso de meio alternativos para produção de bioinseticida à base de Bacillus thuringiensis. Circular Técnica 60. Embrapa, 2005, Sete Lagoas-MG.

VOSS GB. Produção de bacillus subtilis em biorreatores airlift e sua aplicação no controle de nematoides de galhas de tomateiro. [dissertation]. Florianópolis: Universidade Federal de Santa Catarina/UFSC; 2013. 